УдК 616.329-007.43-072.1-089.819

DOI 10.11603/2414-4533.2017.3.8111

М. М. ГАЛЕЙ, І. О. БАБІН, І. Ю. ШАВАРОВ

Волинська обласна клінічна лікарня

\title{
Симультанні лапароскопічні операційні втручання у хворих із комбінованою патологіею органів черевної порожнини
}

\begin{abstract}
У статті представлено аналіз результатів хірургічного лікування хворих із супутньою хірургічною патологією, яка складала 108 (33 \%) від загального числа хворих. Хворим із грижею стравохідного отвору діафрагми та пахвинною грижею проведено лапароскопічну крурорафію з фундоплікацією за Тупе і трансабдомінальну алогерніопластику; хворим із грижею стравохідного отвору діафрагми та пупковою грижею проведено лапароскопічну крурорафію з фундоплікацією за Тупе і грижосічення з пластикою за Мейо; хворим із грижею стравохідного отвору та жовчнокам’яною хворобою проведено лапароскопічну крурорафію з фундоплікацією за Тупе і лапароскопічну холецистектомію.
\end{abstract}

Ключові слова: грижа стравохідного отвору діафрагми; фундоплікація; лапароскопічна крурорафія.

Грижа стравохідного отвору діафрагми (ГСОД) за поширенням “успішно конкурує” з дуоденальними виразками, хронічним холециститом та панкреатитом.

При аналізі частоти захворюваності залежно від віку встановлено, що дане захворювання зустрічається у 0,7 \% від усіх осіб молодше 50 років, 1,2 \% осіб віком від 51 до 60 років, 4,7 \% - в осіб старше 60 років.

У жінок вона діагностується частіше, ніж у чоловіків.

Основними причинами виникнення ГСОД $є$ значне підвищення тиску в черевній порожнині, хронічні хвороби, які супроводжуються тривалим блюванням або кашлем, надмірні фізичні навантаження, пологи, хронічні закрепи, метеоризм.

ГСОД частіше зустрічаються у людей віком понад 50 років, що пов'язано з ослабленням зв’язкового апарату.

Найчастіше грижі стравохідного отвору діафрагми вперше виявляють при проведенні рентгенографій органів грудної клітки, стравоходу і шлунка або під час ендоскопічного обстеження (езофагоскопія, гастроскопія).

В умовах клініки пацієнтів із ГСОД оперують із 2009 року. Прооперовано 325 хворих з ГСОД, що складає 6,5 \% від загальної кількості прооперованих хворих. Чоловіків було 48 (14,7 \%), жінок - 277 (85,3 \%). У віковому аспекті: до 50 років 13,6 \% (43 хворі), від 51 до 60 років - 32,7 \% (107 хворих), старше 60 років - 53,7 \% (175 хворих).

Діагностичний алгоритм обстеження включав аналіз даних лабораторних методів обстеження (загальний та біохімічний аналізи крові, аналіз сечі, коагулограма та ін.), дані інструментального обстеження (УЗД, КТ, ФГДС, МRСР при необхідності), а також дані анамнезу та огляду пацієнта.
Операційне втручання виконували під загальним знеболенням за дапомогою відеокомплексів фірм “Olympus” та “MGB”.

При рентгенологічному обстеженні оцінювали високе розташування стравохідного сфінктера, знаходження абдомінального відділу стравоходу та піддіафрагмального відділу стравоходу над діафрагмою, розміри стравохідного отвору діафрагми, затримка барієвої суспензії в грижовому мішку та ін.

Ендоскопічні ознаки ГСОД: зміщення стравохідно-шлункової лінії вище діафрагми, при інверсії - пролабація шлунка, ознаки езофагіту і гастриту, ерозії та виразки слизової стравоходу.

Для виключення пухлин стравоходу проводиться ендоскопічна біопсія слизової та морфологічне дослідження біоптату. Всім хворим виконано лапароскопічну крурорафію з фундоплікацією за Тупе. Кількість хворих з супутньою хірургічною патологією складала 108 (33 \%). 8 хворим із ГСОД та пахвинною грижею проведено лапароскопічну крурорафію з фундоплікацією за Тупе і трансабдомінальну алогерніопластику (ТАРP). 33 хворим із ГСОД та пупковою грижею проведено лапароскопічну крурорафію з фундоплікацією за Тупе і грижосічення з пластикою за Мейо. 67 пацієнтам із ГСОД та жовчнокам’яною хворобою (ЖКХ) проведено лапароскопічну крурорафію з фундоплікацією за Тупе і лапароскопічну холецистектомію. Остання група пацієнтів, у яких діагностовано ГСОД та ЖКХ, оперована без введення додаткових троакарів. У трьох хворих була конверсія, з них: у двох - $з$ приводу кровотечі (аберантна печінкова артерія) та лейоміома кардіального відділу стравоходу.

Всього інтраопераційні ускладнення спостерігали у 20 хворих (6,2 \%), а саме: кровотечу - 3 
хворих (0,92 \%), перфорацію стінки стравоходу один хворий (0,3 \%), пошкодження паренхіми печінки - 10 хворих (3,1 \%), пошкодження паренхіми селезінки - 3 хворих (0,92 \%), пошкодження парієтальної плеври - 3 хворих (0,92%).

У післяопераційний період спостерігали дисфагію у 5 хворих (1,55 \%), рецидив ГСОД - 2 хворих (0,6 \%).

\section{СПИСОК ЛІТЕРАТУРИ}

1. Kim H. Laparoscopic-assisted combined colon and liver resection for primary colorectal cancer with synchronous liver metastases: initial experience / H. Kim, B. Lim, H. Ha [et al.] // World J. Surg. - 2008. - Vol. 32(12). - P. 2701-2706.

2. Simultaneous Operation of Laparoscopic Fenestration of Hepatic Cyst and Laparoscopic Cholecystectomy / M. Takeyuki, K. Yoshida, S. Kohno, M. Matsuda // Surgical Laparoscopy Endoscopy \& Percutaneous Techniques. - 1994. - Vol. 4 (6). - P. 497.

3. Laparoscopic hepatic left lateral lobectomy combined with fiber choledochoscopic exploration of the common bile duct and traditional open operation / K. Zhang, S. Zhang, Y. Jiang, P. Gao //

\section{REFERENCES}

1. Kim, H., Lim, B. \& Ha, H. (2008). Laparoscopic-assisted combined colon and liver resection for primary colorectal cancer with synchronous liver metastases: initial experience. World J. Surg., 32 (12), 2701-2706.

2. Takeyuki, M., Yoshida, K., Kohno, S., \& Matsuda, M. (1994). Simultaneous operation of laparoscopic fenestration of hepatic cyst and laparoscopic cholecystectomy. Surgical Laparoscopy Endoscopy \& Percutaneous Techniques, 4 (6), 497.

3. Zhang, K., Zhang, S., Jiang, Y., \& Gao, P. (2008). Laparoscopic hepatic left lateral lobectomy combined with fiber choledochoscopic exploration of the common bile duct and traditional open operation.
Лапароскопічна крурорафія з фундоплікацією $є$ операцією вибору при ГСОД.

Виконання малоінвазивного хірургічного лікуання у хворих із ГСОД сприяє зменшенню терміну перебування хворого в стаціонарі, скороченню часу реабілітації в післяопераційний період, покращенню якості життя в післяопераційний період.

World J. Gastroenterol. - 2008. - Vol. 14(7). - P. 1133-1136. 4. Laparoscopic resection of colon cancer and synchronous liver metastasis / M. Geiger, D. Tebb, E. Sato [et al.] // J. Laparoendosc. Adv. Surg. Tech. - 2006. - Vol. 16 (1). - P. 51-53.

5. Romero R. Laparoscopic treatment of simultaneous tumors in the liver and kidney / R. Romero, A. Wagner, S. Bagga [et al.] // Urol. Int. - 2007. - Vol. 79(2). - P. 142-144

6 . Infrarenal aortic aneurysm repair by retroperitoneal approach combined with laparoscopic cholecystectomy: two case reports / N. Wolosker, K. Nishinari, B. Ferrari, L. Nakano // J. Laparoendosc. Adv. Surg. Tech. - 2001. - Vol. 11 (2). - P. 115-117.

World J. Gastroenterol., 14 (7), 1133-1136.

4. Geiger, M., Tebb, D., \& Sato, E. (2006). Laparoscopic resection of colon cancer and synchronous liver metastasis. J. Laparoendosc. Adv. Surg. Tech., 16 (1), 51-53.

5. Romero, R., Wagner, A., \& Bagga, S. (2007). Laparoscopic treatment of simultaneous tumors in the liver and kidney. Urol. Int., 79 (2), 142-144.

6. Wolosker, N., Nishinari, K., Ferrari, B., \& Nakano, L. (2001). Infrarenal aortic aneurysm repair by retroperitoneal approach combined with laparoscopic cholecystectomy: two case reports. J. Laparoendosc. Adv. Surg. Tech., 11 (2), 115-117.

Отримано 23.06.2017

\section{EXPERIENCE OF IMPLEMENTING SIMULTANEOUS LAPAROSCOPIC SURGICAL INTERVENTIONS IN PATIENTS WITH A COMBINED PATHOLOGY OF THE ABDOMINAL CAVITY}

\footnotetext{
The paper presents an analysis of the results of surgical treatment of patients with concomitant surgical pathology, which comprised 108 (33\%) of the total number of patients. Laparoscopic cruroplasty with Tupe fundoplication and transabdominal alorhernioplasty (TAPP) were conducted for patients with hital hernia and inguinal hernia, laparoscopic cruroplasty with Tupe fundoplication and herniotomy with Meyo plastic were carried for patients with hiatal hernia and umbilical hernia, laparoscopic cruroplasty with Tupe fundoplication and laparoscopic cholecystectomy were conducted for patients with hiatal hernia and gallstone disease.
}

Key words: hiatal hernia; fundoplactation; laparoscopic cruroplasty. 
Н. М. ГАЛЕЙ, И. А. БАБИН, И. Ю. ШАВАРОВ

Волынская областная клиническая больница

\section{СИМУЛЬТАННЫЕ ЛАПАРОСКОПИЧЕСКИЕ ОПЕРАТИВНЫЕ ВМЕШАТЕЛЬСТВА У БОЛЬНЫХ С КОМБИНИРОВАННОЙ ПАТОЛОГИЕЙ ОРГАНОВ БРЮШНОЙ ПОЛОСТИ}

В работе представлен анализ результатов хирургического лечения больных с сопутствующей хирургической патологией, которая составляла 108 (33\%) от общего числа больных. Больным с ГПОД и паховой грыжей выполнено лапароскопическую крурорафию с фундопликацией по Тупэ и трансабдоминальную аллогерниопластику, больным с ГСОД и пупочной грыжей выполнено лапароскопическую крурорафию с фундопликацией по Тупэ и грыжесичение с пластикой по Мейо, больным с ГПОД и ЖКБ выполнено лапароскопическую крурорафию с фундопликацией по Тупэ и лапароскопическую холецистэктомию.

Ключевые слова: грыжа пищеводного отверстия диафрагмы; фундопликация; лапароскопическая крурорафия. 